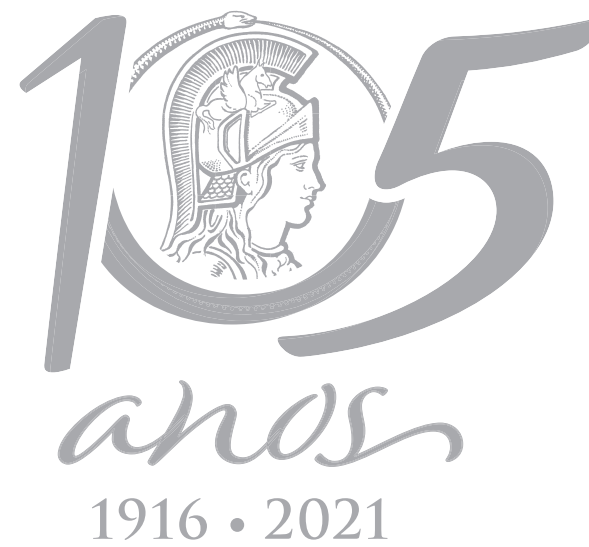

$1916 \cdot 2021$

\title{
Isolation of 2 simazine-degrading bacteria and development of a microbial agent for bioremediation of simazine pollution
}

\author{
JIANGWEI ZHU, YAN ZHAO, XIAOLOU LI, LEI WU, LI FU, NING YANG, JUN YIN \& \\ RONG HUANG
}

\begin{abstract}
Simazine was one of the most commonly used herbicides and was widely used to control broadleaf weeds in agriculture and forestry. Its widespread use had caused wide public concern for its high ecological toxicity. In order to remove simazine residues, 2 strains capable of effectively degrading simazine were isolated from the soil and named SIMA-N5 and SIMA-N9. SIMA-N5 was identified as Bacillus licheniformis by 16SrRNA sequence analysis, and SIMA-N9 was Bacillus altitudinis. According to the degradation ratio of simazine in a certain period of time, the degradation ability of different strains was evaluated. The degradation efficiency of simazine $(5 \mathrm{mg} / \mathrm{L}$ ) by SIMA-N9 could reach about $98 \%$ in 5d, and the strain SIMA-N5 could reach $94 \%$ under the same conditions. In addition, the addition of Pennisetum rhizosphere soil during the process of degrading simazine by strain SIMA-N9 could effectively improve the degradation efficiency. The strain SIMA-N9 has been developed as a microbial agent for the bioremediation of simazine contamination in soil. The new microbial agent developed by using SIMA-N9 has achieved satisfactory application effects. Based on the research results already obtained in this study, it was considered that strain SIMA-N9 and its live bacterial agent could play an important role in bioremediation of simazine pollution. This study could not only provide a set of solutions to the simazine pollution, but also provide a reference for the treatment of other pesticide pollution.
\end{abstract}

Key words: Bacillus altitudinis, Bacillus licheniformis, biodegradation, s-triazine herbicides, live bacteria preparation.

\section{INTRODUCTION}

The worldwide human population boost and expansion of industry and agriculture as well as climate change have resulted in a consequential increase in the chemical wastes upon natural ecosystems (Dauda et al. 2019, Islam et al. 2019). Especially in agricultural production, the extensive use of pesticides such as herbicides, insecticides and fungicides has caused serious adverse effects on the environment. Simazine (CAS:122-34-9) was one of the most commonly used s-triazine herbicides and was widely used to control broadleaf weeds in agriculture and forestry, especially in sugarcane, corn and orchard fields (Li et al. 2018, Silva \& lyer 2014). Its widespread use has caused wide public concern for its moderate persistent in the soil and aquatic environments and high ecological toxicity (Morgante et al. 2010, 2012, Garmouma et al. 2001). Under different environmental conditions, the half-life of simazine was usually from 1 month to 5 months, with an average of about 2 months (Spurlock et al. 2000). In many European countries, simazine was specifically prohibited due to its potential endocrine and 
carcinogenic activity (Sai et al. 2015, Zhang et al. 2011). But it was still one of the most widely used herbicides in the United States, Australia and many other countries (Morgante et al. 2012, Flores et al. 2009, José et al. 2010). Up to now, simazine has been used in China for more than 30 years. According to statistics, in 2006, the United States used about 5-7 million pounds of simazine in agricultural and non-agricultural fields (Marriage et al. 2010). Therefore, the rapid removal of simazine from the contaminated site was considered essential for the safe ecological environment and human health. The United States EPA's Office of Water had established a Maximum Contaminant Level (MCL) for simazine in drinking water of 4.0 parts per billion (ppb). In order to remove simazine from the polluted environment, some techniques have been practiced in the past, such as ozonation, Fenton's oxidation, bioreactor, photodegradation and microbial degradation (Addorisio et al. 2011, Chen et al. 2019, Kang et al. 2020, Sathishkumar et al. 2014, Zhu et al. 2020b). In addition, membrane treatment technology may play an important role in the removal of simazine from water (Meng et al. 2020, Zhang \& Jiang 2019, Zhang et al. 2021). Among the various technologies available for simazine mineralization, the microbial degradation showed better prospects than other methods (Mondragón-Parada et al. 2008, Wan et al. 2014). Microbial degradation usually played a major role in attenuating s-triazine herbicides from contaminated environment.

For bioremediation of simazinecontaminated soils, it was of practical importance to select highly efficient degrading strains or consortia that have strong viability in soil. There have been some reports about simazine biodegradation by strains of bacteria (Guo et al. 2014, Iwasaki et al. 2007), fungi (Blaszak et al. 2011), or microbial community (Grigg et al. 1997, Castro-González et al. 2011)
The use of microorganisms for bioremediation of simazine-contaminated sites was receiving increasing attention as a popular alternative to chemical remediation because it was cost effective and environmentally friendly (Satsuma 2010, Zhu et al. 2019a). However, the degradation efficiencies of the simazine-degrading strains were not satisfactory in most cases, and no simazine-degrading strain has been used for commercial purposes. Therefore, in order to solve the environmental problems caused by simazine pollution, it was necessary to isolate high-efficiency simazine-degrading strains and study their degradation characteristics (Caracciolo et al. 2007).

Extensive research has addressed the behavior of simazine in the soil, the identification and isolation of the degrading strains, and the biodegradation pathway of simazine and related s-triazines. In the biodegradation process of simazine, intermediate compounds such as ammeline, ammelide and cyanuric acid were usually produced (Caracciolo et al. 2005, Raquel et al. 2005). Some intermediates may have higher stability or other biological activities and may have a negative impact on the surrounding environment and related organisms (Morgante et al. 2012, Caracciolo et al. 2005). Therefore, the attention should also be paid to these intermediate metabolites (Navarro et al. 2000, Kearney et al. 1965). In addition, many factors usually affect the biodegradation of simazine, such as pH, temperature and plant roots (Morán et al. 2010, Behki \& Khan 1994, Zhu et al. 2019b). Some plants (eg. Pennisetum alopecuroides) could also affect the degradation of simazine in soil (Singh et al. 2004, Liao \& Xie 2008, Lu et al. 2020). Therefore, in addition to screening highefficiency simazine-degrading strains, various factors affecting the biodegradation of simazine should also be highlighted. 
In this study, two strains capable of effectively degrading simazine (SIMA-N5 and SIMA-N9) were isolated. The degradation efficiency and characteristics of two simazinedegrading strains were studied and compared. The effects of some plants' rhizosphere soil on the biodegradation of simazine and the important intermediate metabolites of simazine were also analyzed. In addition, based on the higher simazine degradation efficiency possessed by strain SIMA-N9, it had been formulated into a microbial agent that could degrade simazine residues. The microbial agent containing SIMA-N9 had achieved initial success and would be commercialized. And it was expected to be used to remove simazine and other s-triazine herbicide residues in soil or water. The isolated simazine-degrading bacteria may also be used for the development of bioreactors or the production of degrading enzymes. The flow chart of the experiment was shown in Fig. 1.

\section{MATERIALS AND METHODS}

\section{Sampling of soils}

0 10 cm soil layer was collected from farmland in Changzhou, China, in which simazine was used for more than six years. The depth of the sampled layer was $0 \mathrm{~cm}, 5 \mathrm{~cm}$ and $10 \mathrm{~cm}$, respectively. A total of 30 soil samples were collected. The collected soil samples were used to isolate simazine-degrading bacteria and for subsequent research.

\section{Chemicals and Media}

Chemicals: simazine (98.6\%), ammelide (99.0\%) and cyanuric acid (99.5\%) were purchased from Sigma-Aldrich Company and Dr. Ehrenstorfer $\mathrm{GmbH}$. Other chemicals used were of analytical grade.

Media: (I). Mineral salt medium (Lanyi Biotechnology Co., Ltd., China): Ammonium sulfate $0.1 \mathrm{~g}$, Dipotassium hydrogenphosphate $0.1 \mathrm{~g}$, Calcium sulfate $0.05 \mathrm{~g}$, Ferrous sulfate heptahydrate $0.01 \mathrm{~g}$, Magnesium sulfate heptahydrate $0.2 \mathrm{~g}, \mathrm{H}_{2} \mathrm{O} 1.0 \mathrm{~L}, \mathrm{pH}$ 7.0. (II). Isolation medium: mineral salt medium containing 5.0 $\mathrm{mg} / \mathrm{L}$ simazine. (III). LB (Luria-Bertani) medium (Lanyi Biotechnology Co., Ltd.): yeast extract 5

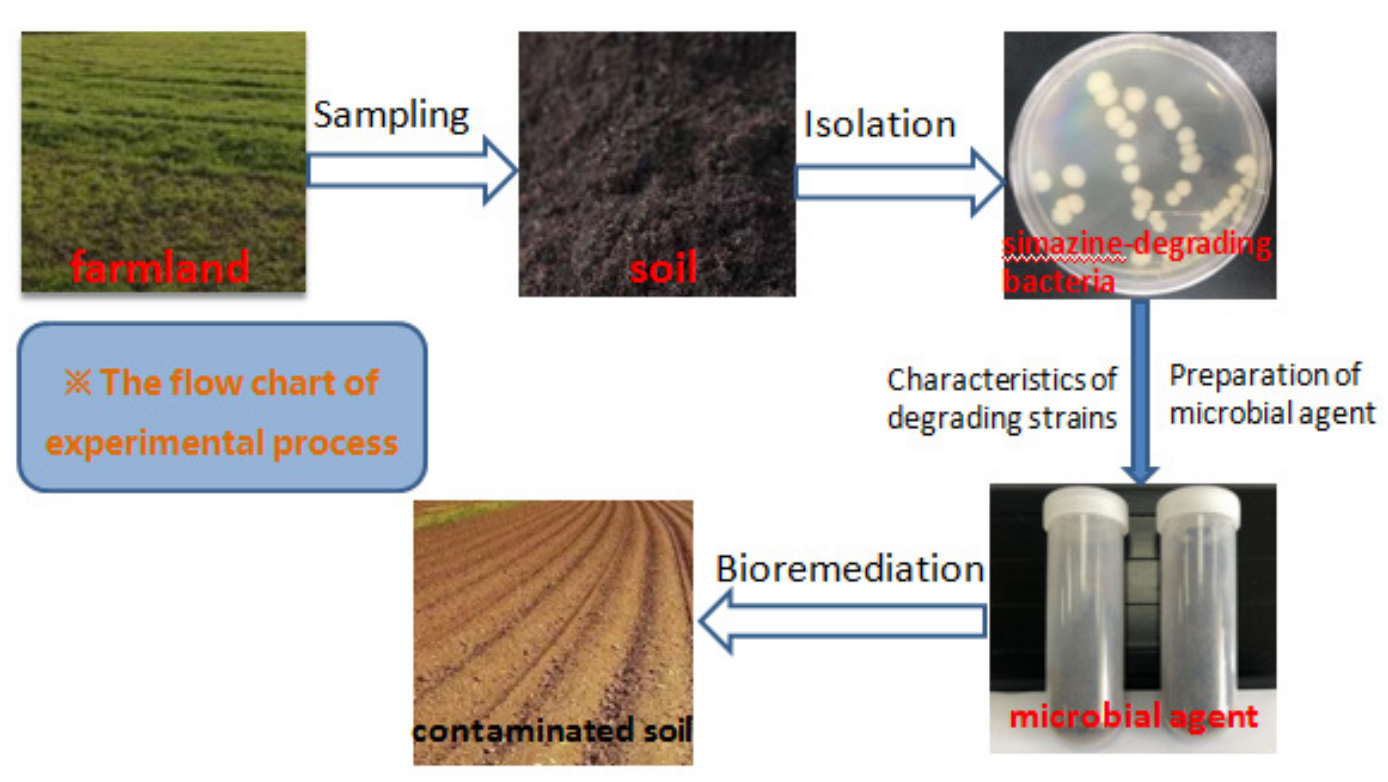

Figure 1. The flow chart of the experiment. 
g, peptone $10 \mathrm{~g}$, NaCl $10 \mathrm{~g}, \mathrm{H}_{2} \mathrm{O} 1.0 \mathrm{~L}$, pH7.0. (IV). Enrichment medium (Lanyi Biotechnology Co., $\mathrm{Ltd}$.): beef extract $5 \mathrm{~g}$, yeast extract $5 \mathrm{~g}$, peptone $7 \mathrm{~g}, \mathrm{NaCl} 5 \mathrm{~g}, \mathrm{H}_{2} \mathrm{O} 1.0$ L, pH7.0.

\section{Isolation of simazine degrading bacteria}

Five grams of soil samples were mixed with $100 \mathrm{ml}$ isolation medium, and incubated at 30 ${ }^{\circ} \mathrm{C}$. The content of simazine in medium was determined regularly. Transfer $5 \mathrm{ml}$ of culture solution with 3-day degradation efficiency $>80 \%$ to an enrichment medium containing 5.0 $\mathrm{mg} / \mathrm{L}$ simazine, and continuously subculture for more than 5 times. After verifying the degradation ability again, the above-mentioned enrichment culture solution was inoculated into an inorganic salt culture plate containing simazine for incubation at $30^{\circ} \mathrm{C}$. The eugonic microbial colonies were selected, and obtained a pure culture by repeated scribing. The new isolates were identified by $16 \mathrm{~S}$ rRNA sequence (Wang \& Xie 2012, Wang et al. 2012, Kou et al. 2020). A phylogenetic tree was made by using ClustalX1.83 and MEGA 5.0.

\section{Preparation of bacterial inoculant}

Simazine-degrading strains, Bacillus licheniformis SIMA-N5 and Bacillus altitudinis SIMA-N9 have been isolated. Two strains were incubated individually in LB medium amended with $5 \mathrm{mg} / \mathrm{L}$ simazine at $30^{\circ} \mathrm{C}$. After overnight incubation, the cells were collected by centrifugation and rinsed with sterile water. Then, the cells were resuspended, and approximately $8 \times 10^{6}$ cells $/ \mathrm{ml}$. This cell suspension will be used as inoculant for subsequent research (Wang \& Xie 2012, Ding et al. 2019, Fan et al. 2020).

\section{Degradation of simazine by strain SIMA-N5 and SIMA-N9}

$6 \%$ strain SIMA-N5 inoculant was inoculated in mineral salt medium containing $5 \mathrm{mg} / \mathrm{L}$ simazine, and incubated at $30^{\circ} \mathrm{C}$ (100rpm). The concentrations of simazine, ammelide and cyanuric acid were determined every $24 \mathrm{~h}$. The strain SIMA-N9 was tested according to the same procedure.

$3 \%$ strain SIMA-N5 inoculant and 3\% SIMA-N9 inoculant were simultaneously inoculated in mineral salt medium containing simazine $(5 \mathrm{mg} / \mathrm{L})$, and incubated under the same conditions as above. The concentrations of simazine, ammelide and cyanuric acid were determined regularly.

\section{Tolerance of strain SIMA-N5 and SIMA-N9 on simazine}

The concentration of simazine in LB medium was adjusted to 25, 50, 100, 200 and $500 \mathrm{mg} / \mathrm{L}$ by applying simazine wettable powder, respectively. Then the strain SIMA-N5 (or SIMA-N9) was inoculated and incubated at $30^{\circ} \mathrm{C}$ with shaking. $\mathrm{OD}_{600}$ was regularly recorded to evaluate the resistance of strains to simazine.

Table I. The parameters of MS/MS analysis.

\begin{tabular}{|c|c|c|c|c|c|}
\hline Compound & Ionization mode & Precursor ion & Product ion & Fragmenter & CE \\
\hline Simazine & positive & 202 & $96 / 104$ & 130 & $13 / 21$ \\
\hline Ammelide & negative & 127 & $84 / 42$ & 120 & $15 / 15$ \\
\hline Cyanuric acid & negative & 128 & $85 / 42$ & 120 & $14 / 20$ \\
\hline
\end{tabular}




\section{Degradation of simazine by combined application of strain SIMA-N9 and fresh soil}

The simazine wettable powder was dissolved in water and added into LB medium, the concentration of simazine in LB medium was 30 $\mathrm{mg} / \mathrm{kg}$. LB medium containing simazine $(30 \mathrm{mg} / \mathrm{L}$ ) was divided into 5 groups, each one was $250 \mathrm{ml}$. (1) Add $7.5 \mathrm{ml}$ of the strain SIMA-N9 inoculum and $5 \mathrm{~g}$ fresh soil to the first group (fresh soil was taken from idle farmland without crops, the depth of the sampled soil layer was about $12 \mathrm{~cm}$. $\mathrm{n}=5$ ). (2) Add $7.5 \mathrm{ml}$ of the strain SIMA-N9 inoculum and $5 \mathrm{~g}$ Pennisetum (Pennisetum.alopecuroides (Linn.) Spreng.) rhizosphere soil, the depth of the sampled soil layer was about $12 \mathrm{~cm}, \mathrm{n}=5$. (3)Add $7.5 \mathrm{ml}$ of the strain SIMA-N9 inoculum and $5 \mathrm{~g}$ soybean (Glycine max (Linn.) Merr.) rhizosphere soil, the depth of the sampled soil layer was about $12 \mathrm{~cm}, \mathrm{n}=5$. (4) Add only $7.5 \mathrm{ml}$ of the strain SIMA-N9 inoculum, $n=5$. (5) Control group. Finally, all 5 groups were incubated at $30^{\circ} \mathrm{C}$, the residual simazine was determined regularly.

\section{Degradation of simazine by combined application of strain SIMA-N9 and soil solution}

First, the soil of idle farmland, the rhizosphere soil of Pennisetum and the rhizosphere soil of soybean were collected separately, and the depth of the sampled soil layer was about 12 $\mathrm{cm}$. Then, $50 \mathrm{~g}$ of soil was mixed with $100 \mathrm{ml}$ of sterile saline and stirred evenly. The mixture was first filtered by three layers of gauze and then filtered by filter paper. Finally, the soil filtrate was filtered and sterilized by sterile syringe filter with $0.2 \mu \mathrm{m}$ Supor membrane(Pall Corporation). The sterilized soil solution was stored in a freezer for subsequent study.

LB media containing simazine $(30 \mathrm{mg} / \mathrm{L}$ ) were divided into 5 groups, each one was $250 \mathrm{ml}$. (1) Add $7.5 \mathrm{ml}$ of the strain SIMA-N9 inoculum and $5 \mathrm{ml}$ sterilized soil solution(from idle farmland) to the first group. (2) Add $7.5 \mathrm{ml}$ of the strain SIMA-N9 inoculum and $5 \mathrm{ml}$ sterilized Pennisetum rhizosphere soil solution. (3) Add $7.5 \mathrm{ml}$ of the strain SIMA-N9 inoculum and $5 \mathrm{ml}$ sterilized soybean rhizosphere soil solution. (4) Add $7.5 \mathrm{ml}$ of the strain SIMA-N9 inoculum and $5 \mathrm{ml}$ of sterile saline. (5) Control group. Finally, all 5 groups were incubated at $30^{\circ} \mathrm{C}$, the residual simazine and $\mathrm{OD}_{600}$ in medium were determined regularly.

\section{Construction of a microbial agent for effective simazine degradation}

\section{Preparation steps for microbial agent containing strain SIMA-N9}

Option A: The strain SIMA-N9 inoculant was mixed with a sterile enrichment medium (1:9, $\mathrm{v} / \mathrm{v})$, the mixture was incubated for 1 day at $30^{\circ} \mathrm{C}$. The mixture of rice hull powder, dried peat soil and fresh Pennisetum rhizosphere soil (6:3:1, w/w) was used as carrier for the preparation of microbial agent, and each 100 g carrier was mixed with $25 \mathrm{ml}$ pre-prepared mixture containing SIMA-N9. The final mixture was incubated at $30^{\circ} \mathrm{C}$ for $15 \mathrm{~h}$, then put them in the sterile vial and stored at $0^{\circ} \mathrm{C}$.

Option B: The mixture of rice hull powder and dried peat soil $(6: 4, \mathrm{w} / \mathrm{w})$ was used as carrier. Other steps were the same as in Option A.

\section{Degradation of simazine in soil by the microbial agent}

An aqueous solution of simazine wettable powder was added to the fresh soil to make the concentration of simazine in soil $30 \mathrm{mg} / \mathrm{kg}$. The soil containing simazine was then dispensed into a $30 \mathrm{~cm} \times 30 \mathrm{~cm}$ plastic box with a soil depth of $12 \mathrm{~cm}$ and the soil weight in each box was the same. 
$1.0 \mathrm{~g}$ of the microbial agent was dissolved in $45 \mathrm{ml}$ of sterile water and then sprinkled all over a box of soil. $45 \mathrm{ml}$ sterile water was sprinkled in control group. Finally, the residual simazine in soil was determined regularly after incubation.

\section{Determination of simazine and its metabolites}

Soil samples were treated in the following steps: $10.0 \mathrm{~g}$ soil sample was weighed into 250 $\mathrm{ml}$ beaker. $10.0 \mathrm{~g}$ anhydrous $\mathrm{Na}_{2} \mathrm{SO}_{4}$ and 100 $\mathrm{ml}$ ethyl acetate were added to each sample. Samples were homogenized for $0.5 \mathrm{~min}(12,000$ rpm), and allowed to settle for 0.5 hours. Filter the extract by quantitative filter paper, $10 \mathrm{ml}$ of filtrate was blown to dryness by nitrogen at $55{ }^{\circ} \mathrm{C}$. The dry extract was redissolved in $2 \mathrm{ml}$ of $\mathrm{CH}_{3} \mathrm{OH}$, then filter into a vial through a 0.22 micron filter (Merck Millipore). All extracts were stored at $0{ }^{\circ} \mathrm{C}$ until analysis (Navarro et al. 2000, Chung et al. 2011).

Liquid samples were centrifuged to obtain cell-free supernatant, which were then analyzed by LC-MS/MS on 1260HPLC-6430 Triple quadrupole mass spectrometer (Agilent, USA). Simazine, ammelide and cyanuric acid were separated on a C18 column (Agilent, 3.0×100 mm, 1.8-Micron) with a flow rate of $0.3 \mathrm{ml} / \mathrm{min} .0 .1 \%$ $\mathrm{HCOOH}$ aqueous solution and $\mathrm{CH}_{3} \mathrm{CN}$ were used for HPLC gradient elution. MS/MS analysis was performed in ESI mode and transitions were measured in MRM (Zhu et al. 2020a).

\section{Statistical analysis}

The statistical analysis of the experimental data was carried out with Excel2013 (Microsoft Software). Data were plotted using Origin (version 8.1).

\section{RESULTS AND DISCUSSION}

\section{Characterization of simazine degrading strains and degradation of simazine by the strain SIMA-N5 and SIMA-N9}

2 strains capable of effectively degrading simazine were isolated from soil and named as SIMA-N5 and SIMA-N9. SIMA-N5 was bacillus, 0.50.8×2.5-3.5 $\mu \mathrm{m}$, Gram positive, aerobic bacteria, motile, and formed pale-yellow and opaque colonies on LB medium. It was positive in tests for oxidase, gelatinase and catalase, but negative for D-glucose fermentation, amylase and urease (Zhao et al. 2019, Song et al. 2020, Xu et al. 2020). SIMA-N5 was identified as Bacillus licheniformis according to $16 \mathrm{~S}$ sequence (GenBank accession No. MN067735).

SIMA-N9 was curvulate bacillus, Gram positive, facultative aerobe, mobile, $0.7-0.8 \times 2.0-$ $3.0 \mu \mathrm{m}$, and it formed grayish and opaque colonies on LB medium. It was positive for urease, amylase, catalase and indole test, but negative for oxidase, gelatinase and methyl red test. SIMA-N9 was identified as Bacillus altitudinis (GenBank accession No. MN067807, phylogenetic tree was shown in Fig. 2). The phylogenetic tree (neighbor-joining tree) was constructed by using ClustalX1.83 and MEGA 5.0.

\section{Degradation of simazine by strain SIMA-N5 and SIMA-N9}

The results in Fig. 3 and Fig. 4 showed that simazine could be rapidly degraded by SIMA-N5 and SIMA-N9. The degradation efficiency of simazine ( $5 \mathrm{mg} / \mathrm{L}$ ) by SIMA-N5 could reach about $98 \%$ in $6 d$, while the strain SIMA-N9 could reach 100\%. It could also be seen from Fig. 5 that SIMA-N9 degraded simazine slightly faster than SIMA-N5. But this did not mean that simazine has been completely degraded. Ammeline, ammelide and cyanuric acid were important metabolites in the degradation of simazine (Caracciolo et al. 2005, 


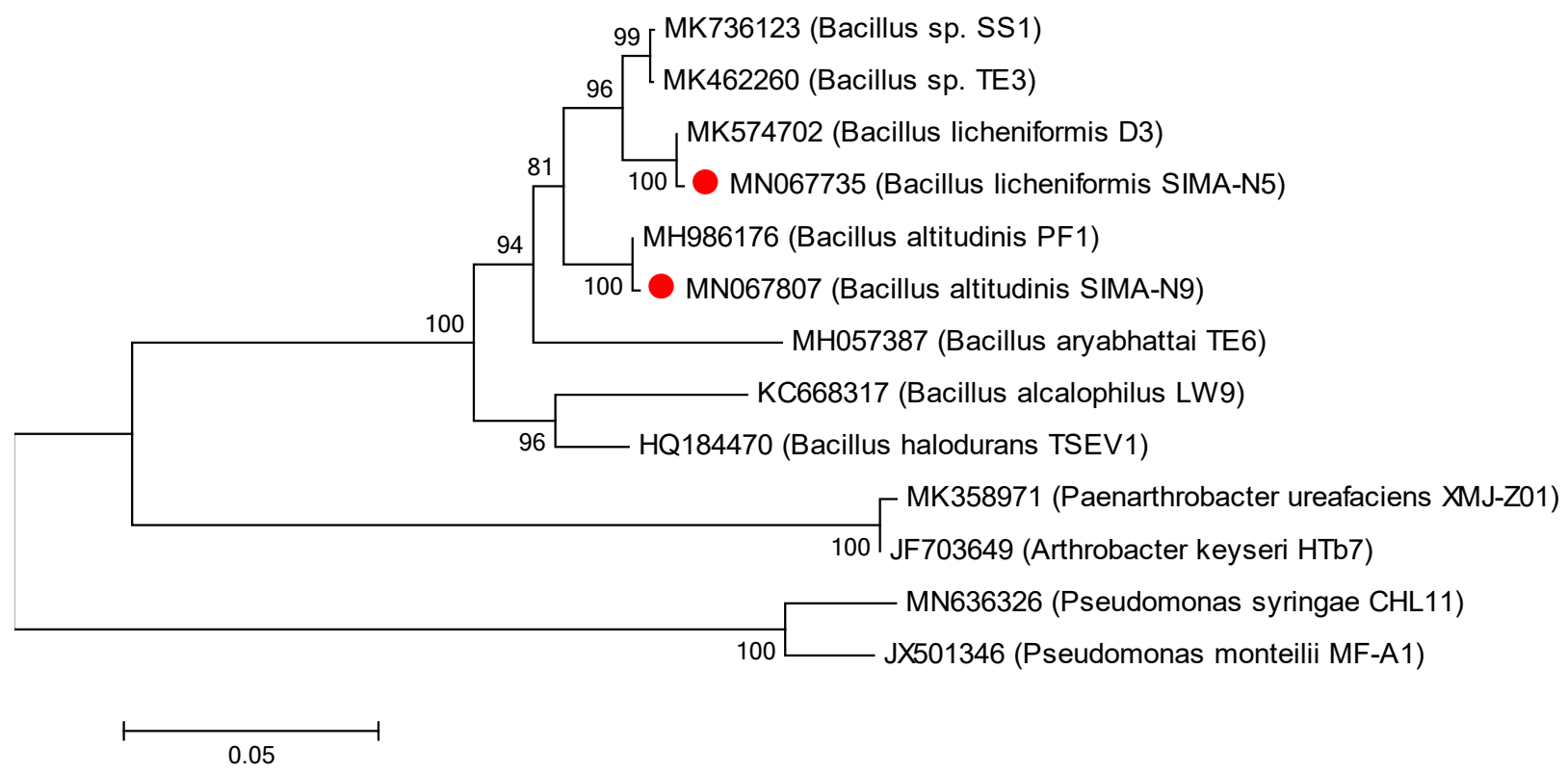

Figure 2. Phylogenetic tree of strain SIMA-N5 and SIMA-N9.

Xia et al. 2015). Ammeline was easy to convert to ammelide or cyanuric acid, resulting in a very low concentration of ammeline in the medium, so ammeline was not analyzed separately in this study. The concentrations of ammelide and cyanuric acid rose first and then fell in Fig. 3 and Fig. 4, which indicated that ammelide and cyanuric acid could be further degraded although there was a staged accumulation of intermediate metabolites during the degradation process. In addition, it was found that the accumulation of ammelide and cyanuric acid during the degradation of simazine by strain SIMA-N5 was significantly higher than that of the strain SIMA-N9 by comparing Fig. 3 with Fig. 4. It could be speculated that strain SIMAN9 could degrade ammelide and cyanuric acid more rapidly. The rapid release of intermediate metabolite accumulation would also facilitate degradation of the parent compound, and it may be an important reason why strain SIMA-N9 could degrade simazine more rapidly than strain SIMA-N5. In this study, two strains were also combined for the degradation of simazine, and the results in Fig. 5 show that the combined application of strain SIMA-N5 and strain SIMA-N9 did not achieve better results. This might be due to the competition or antagonism between the two strains, which would affect the degradation efficiency.

\section{Tolerance of strain SIMA-N5 and SIMA-N9 on simazine}

If the concentration of simazine was increased from $25 \mathrm{mg} / \mathrm{L}$ to $200 \mathrm{mg} / \mathrm{L}$ (Fig. 6), $\mathrm{OD}_{600}$ of strain SIMA-N5 did not change significantly $(P>0.05)$. However, $200 \mathrm{mg} / \mathrm{L}$ of simazine significantly inhibited the growth of strain SIMA-N9 (Fig. 7). $500 \mathrm{mg} / \mathrm{L}$ of simazine would lead to a greater reduction in $O D_{600}$ of strain SIMA-N9, while also could significantly inhibit the growth of strain SIMA-N5. Based on the available data, it was preliminarily concluded that the strain SIMA-N5 was better tolerant to simazine than the strain SIMA-N9. In addition, although 500 mg/L of simazine could significantly inhibit the growth of strain SIMA-N5 and SIMA-N9, it did not cause them to stop growing, which also indicated that the two strains were well tolerated to simazine. 


\section{Degradation of simazine by strain SIMA-N9 and soil (or the sterilized soil solution)}

Based on the higher simazine degradation efficiency of strain SIMA-N9, strain SIMA-N9 would be selected for subsequent application studies (but did not deny the application potential of strain SIMA-N9). The results shown in Fig. 8 indicated that the combination of strain SIMA-N9 and fresh soil for the degradation of simazine could achieve higher degradation efficiency. The highest degradation efficiency was obtained when strain SIMA-N9 was combined with the rhizosphere soil of Pennisetum, and the 6-day degradation rate of simazine $(30 \mathrm{mg} /$ $\mathrm{kg}$ ) was $100 \%$. If soybean rhizosphere soil or idle farmland soil was combined with strain SIMA-N9 for degradation of simazine, its degradation efficiency was significantly higher than that of strain SIMA-N9 alone, which might be due to the fact that some microorganisms and enzymes in soil were involved in the degradation of simazine or play a supporting role. These microorganisms and soil enzymes in soil may be involved in the deamination, dealkylation or dechlorination of simazine, but cannot completely mineralize simazine. They may only participate in the degradation of the intermediate metabolites of simazine, but it will facilitate the mineralization of simazine (Douglass et al. 2017, Silvia et al. 2011, Jin et al. 2020). In this study, the application of Pennisetum rhizosphere soil significantly improved the degradation efficiency of simazine, but it was not confirmed which factor in the rhizosphere soil was working, possibly soil microbes, soil enzymes, or other biological factors(Douglass et al. 2017, Min et al. 2019).

The soil solution used here was filtered to remove microorganism by $0.2 \mu \mathrm{m}$ Supor ${ }^{\circledR}$ membrane to eliminate the effects of soil microorganisms on the experiment. The results in Fig. 9 indicated that the combination of the rhizosphere soil solution of Pennisetum and strain SIMA-N9 for the degradation of simazine could achieve higher degradation efficiency than other soil solutions. The degradation efficiency of simazine in the combination of soybean rhizosphere soil solution (or idle farmland soil solution) and strain SIMA-N9 was similar to that of strain SIMA-N9 alone ( $P>0.05)$. In addition, according to the results shown in Fig. 10, although the combination of Pennisetum rhizosphere soil solution and strain SIMA-N9 could obtain higher simazine degradation efficiency, $O_{600}$ of strain SIMA-N9 in the experimental group of Pennisetum rhizosphere soil solution was not significantly different from that of soybean rhizosphere soil solution group (or idle farmland soil solution). This indicated that the highest simazine degradation efficiency obtained by the combination of the rhizosphere soil solution of Pennisetum and strain SIMA-N9 in Fig. 9 was not due to the accelerated growth of strain SIMA-N9. It was concluded that the rhizosphere soil solution of Pennisetum may contain some enzymes or other compounds that could promote the degradation of simazine, and such enzymes or other related compounds may be valuable for the treatment of simazine pollution. The application of the rhizosphere soil of Pennisetum in Fig. 8 led to an increase in the degradation efficiency of simazine, which could not rule out the role of microbes in Pennisetum rhizosphere soil. In Fig. 8, the degradation efficiency of simazine in the rhizosphere soil of soybean (or idle farmland soil) combined with strain SIMA-N9 was higher than that of strain SIMA-N9 alone, but this phenomenon was not observed after the soil solution was sterilized by filtration in Fig. 9, so it was inferred that this phenomenon in Fig. 8 was mainly due to the action of microorganisms in the soil. 


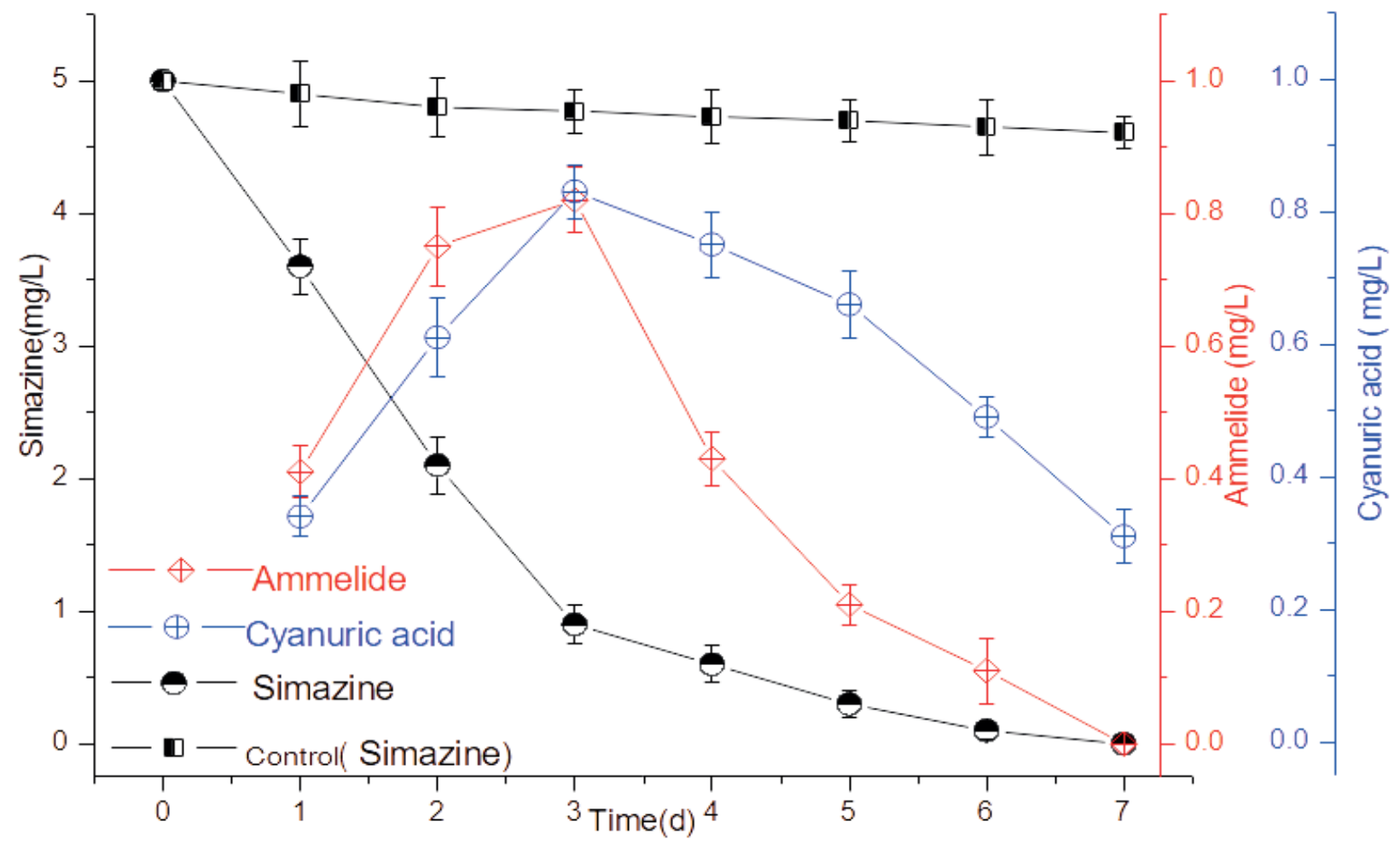

Figure 3. The curve on degradation of simazine by the strain SIMA-N5 ( $n=5)$.

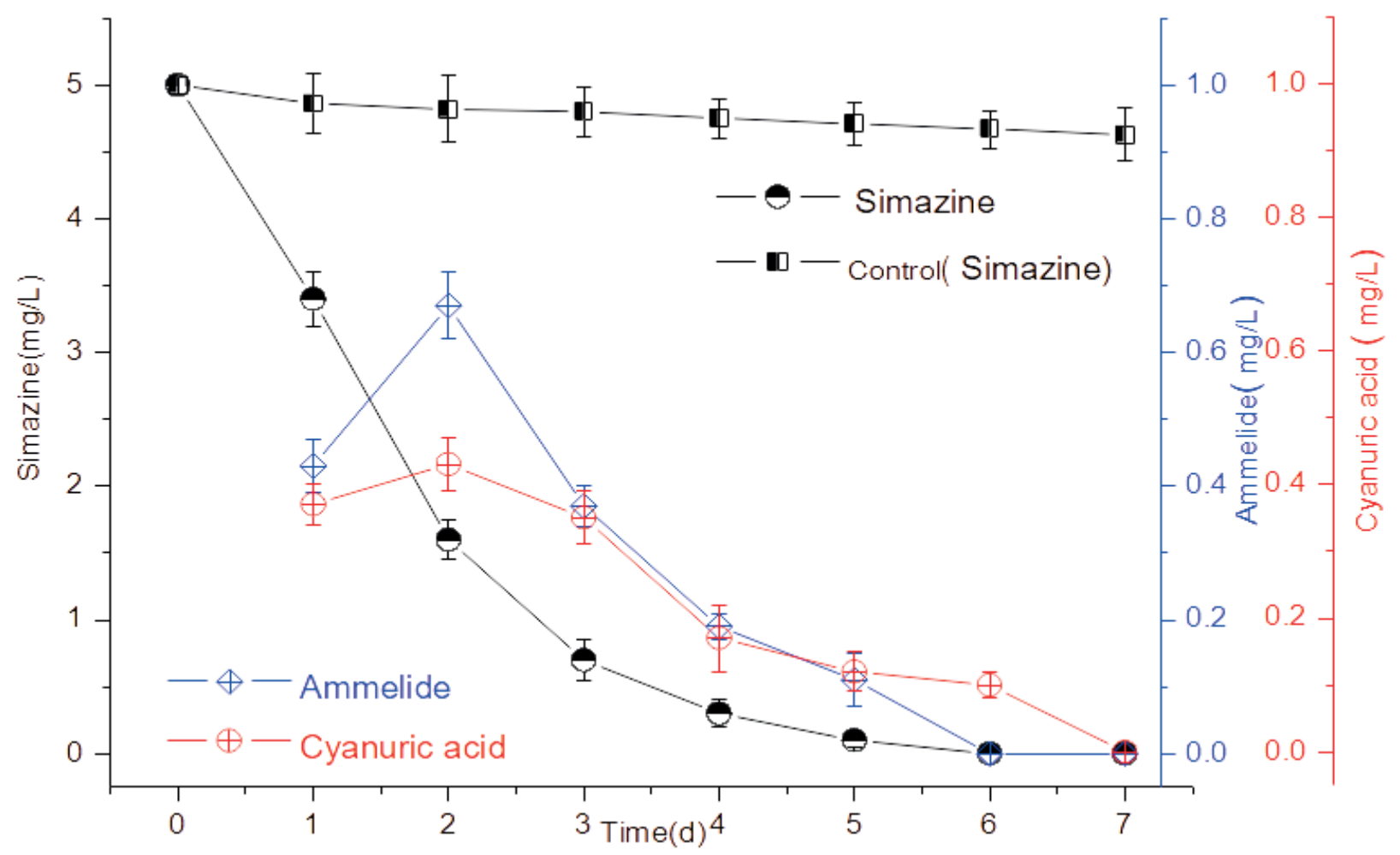

Figure 4. The curve on degradation of simazine by the strain SIMA-N9 $(n=5)$. 


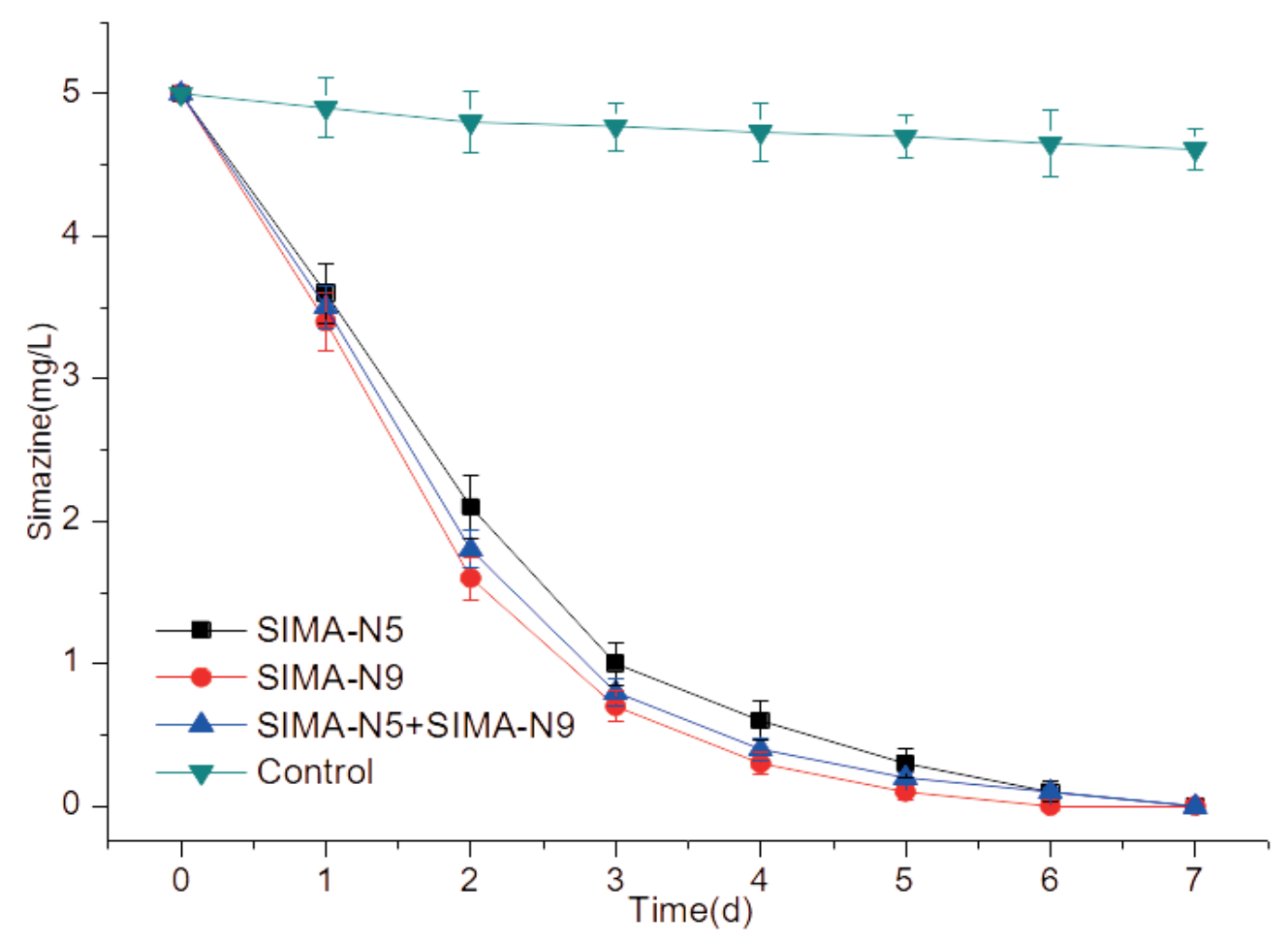

Figure 5. The curve on degradation of simazine by different microorganisms $(n=5)$.

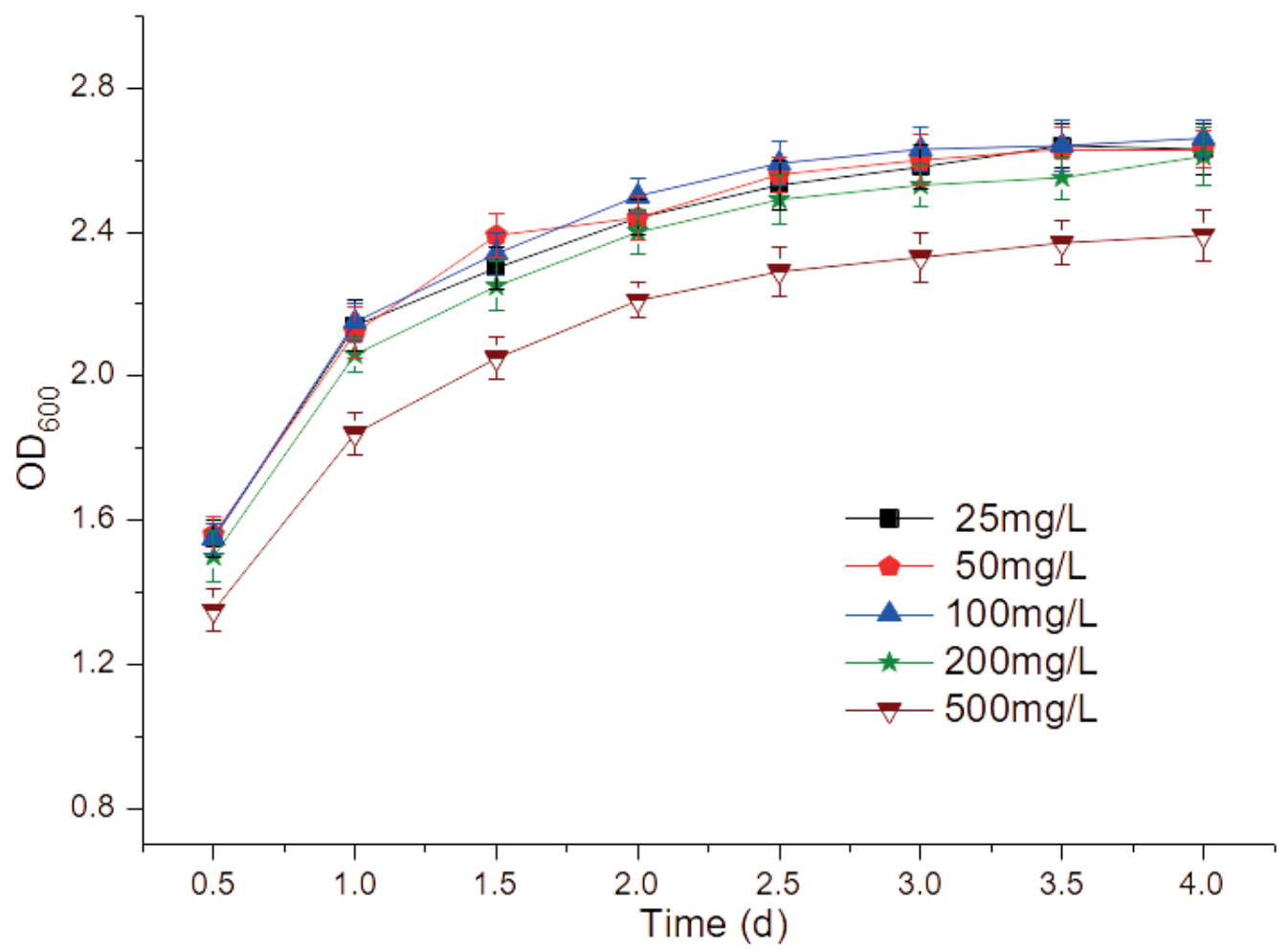

Figure 6. Effect of concentration of simazine on the growth of SIMA-N5 $(n=5)$. 


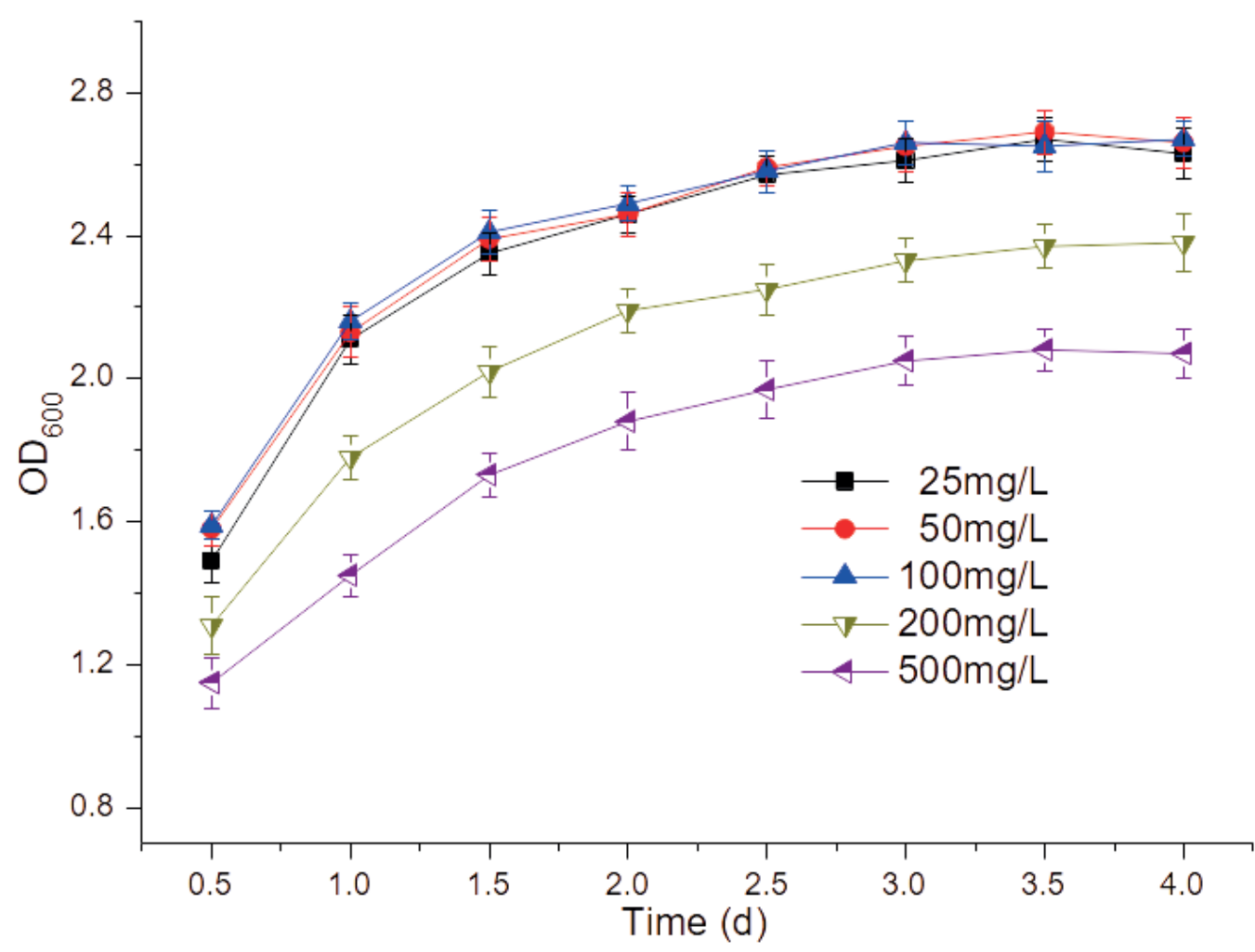

Figure 7. Effect of concentration of simazine on the growth of SIMA-N9 $(n=5)$.

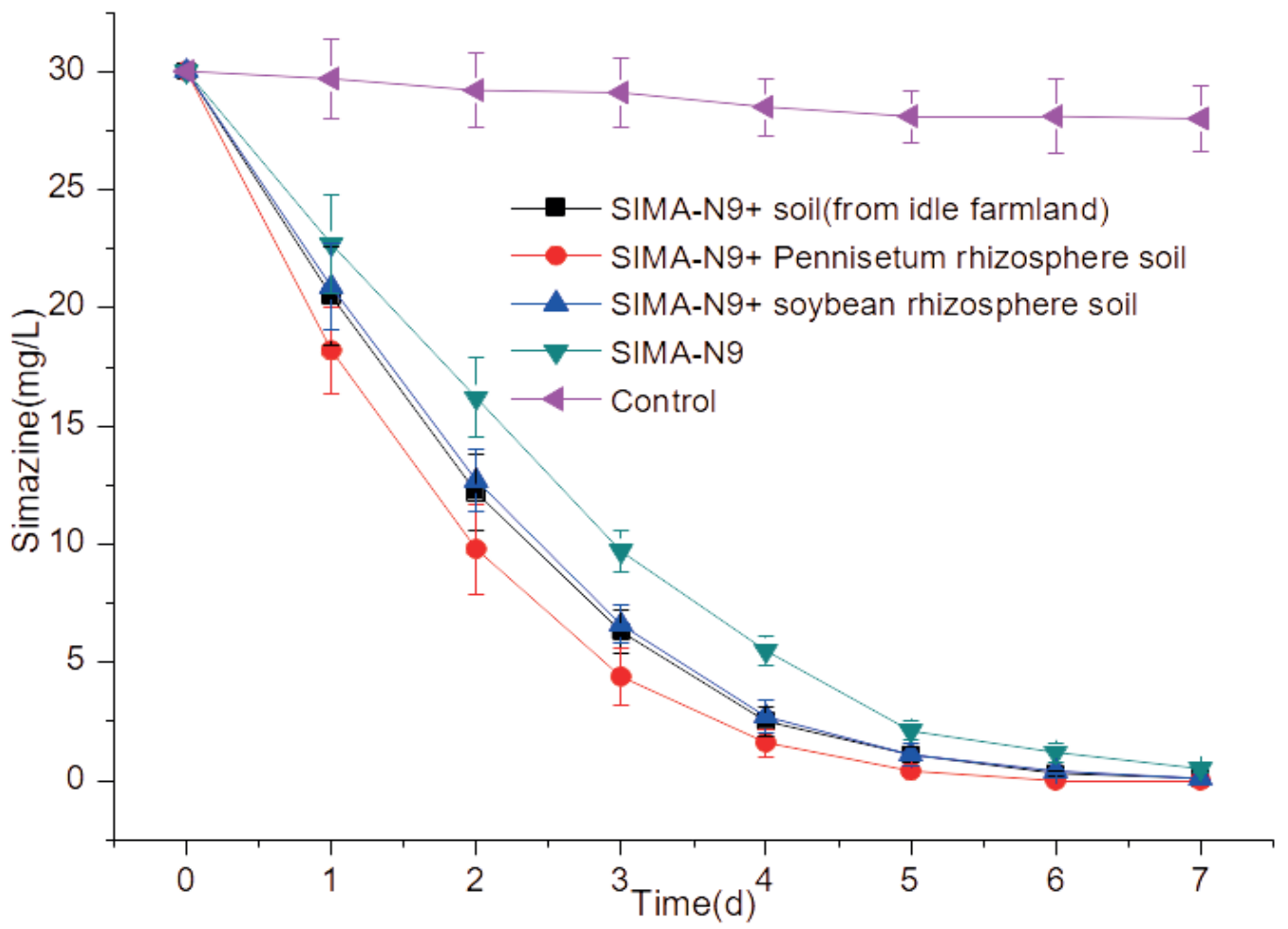

Figure 8.

Degradation of simazine by strain SIMA-N9 and soil $(n=5)$. 


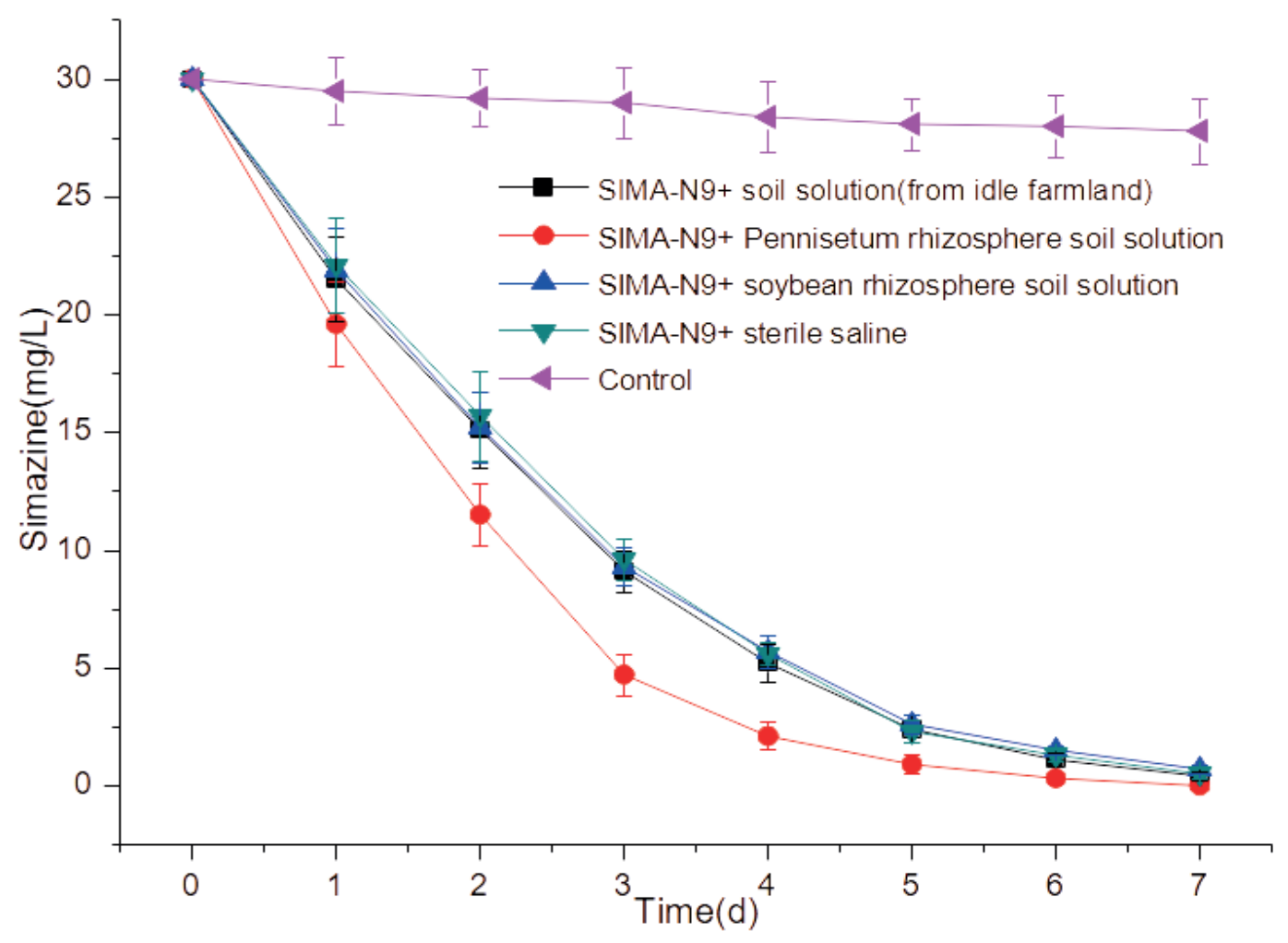

Figure 9.

Degradation of simazine by strain SIMA-N9 and the sterilized soil solution $(n=5)$.

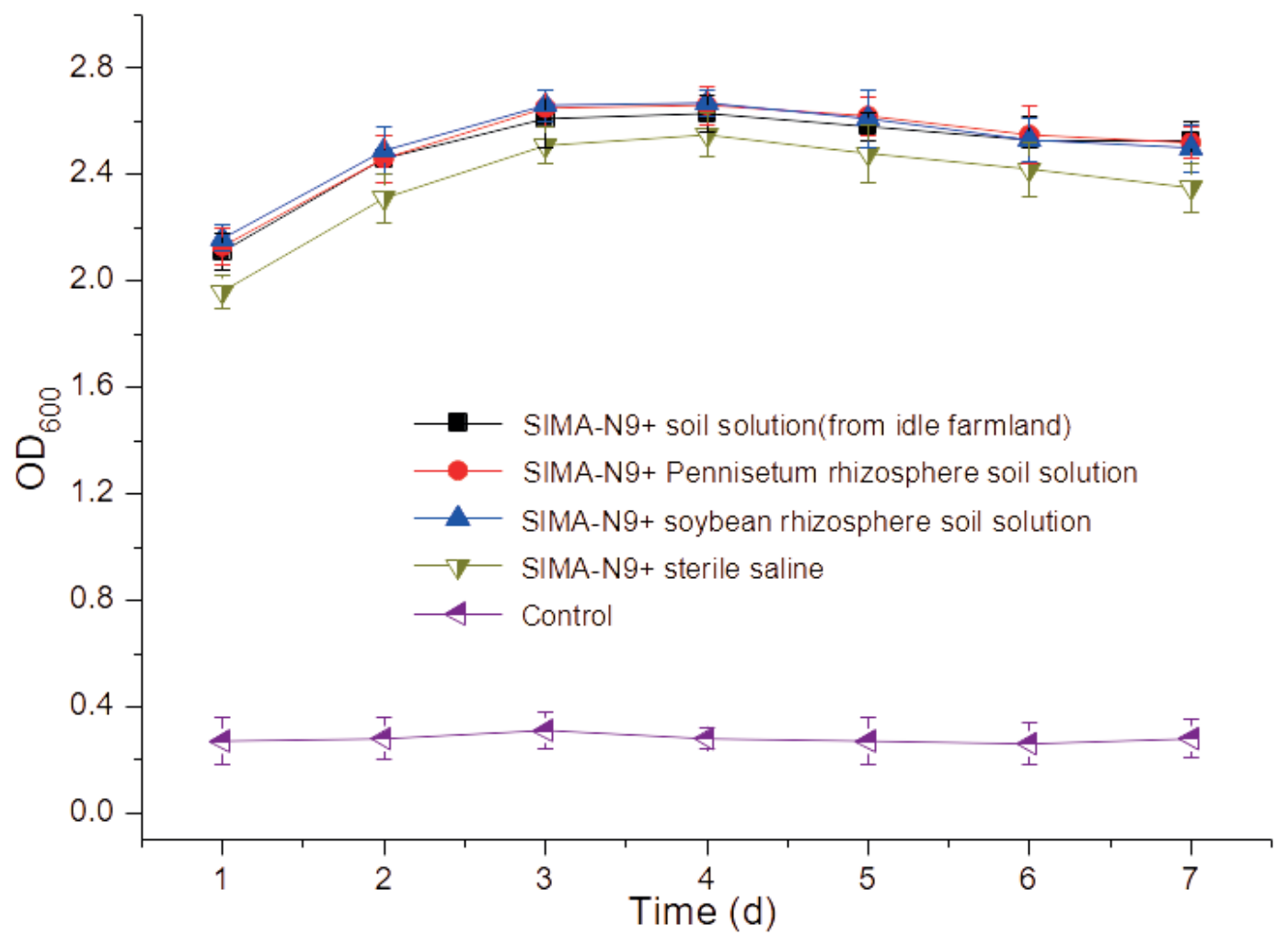

Figure 10.

$\mathrm{OD}_{600}$ curve during the degradation of simazine by strain SIMA-N9 and soil solution $(n=5)$. 


\section{Degradation of simazine by the microbial agent}

Bioaugmentation with pure cultures or microbial consortia was an attractive option for removing simazine or other s-triazine herbicides from the contaminated sites (Hernandez et al. 2010, Zhu et al. 2021, Herrera et al. 2019). In general, in order to ensure the effect of bioaugmentation, it was necessary to prepare an efficient microbial agent which was easy to store and use. According to the above experimental data, it was predicted that the proper addition of the rhizosphere soil of Pennisetum during the preparation of the microbial agent would be beneficial to improve the degradation efficiency of simazine. The experimental results of degrading simazine in soil by using the above microbial agents were shown in Fig. 11. The microbial agent containing the rhizosphere soil of Pennisetum could achieve a 7-day degradation efficiency of 100\% for simazine $(30 \mathrm{mg} / \mathrm{kg})$. If the rhizosphere soil of Pennisetum was not added during the preparation of the live bacterial agent, the final simazine degradation efficiency was slightly reduced (Fig. 11). Therefore, in the preparation of the live microbial agent, it was also necessary to pay attention to some factors such as related adjuvants. In the process of microbial degradation under artificial intervention, the survival of bioaugmentation strains was an issue that must be paid attention to (Zhu et al. 2018, Cho et al. 2008, Xu et al. 2019). It was speculated that SIMA-N9 could survive well in soil or microbial agent because the microbial agent containing SIMA-N9 could effectively degrade simazine in soil. The degradation efficiency of simazine was 32\% after 7 days in the control group (no microbial agent), which should be attributed to the role of soil enzymes, indigenous microorganisms and other soil biochemical factors.

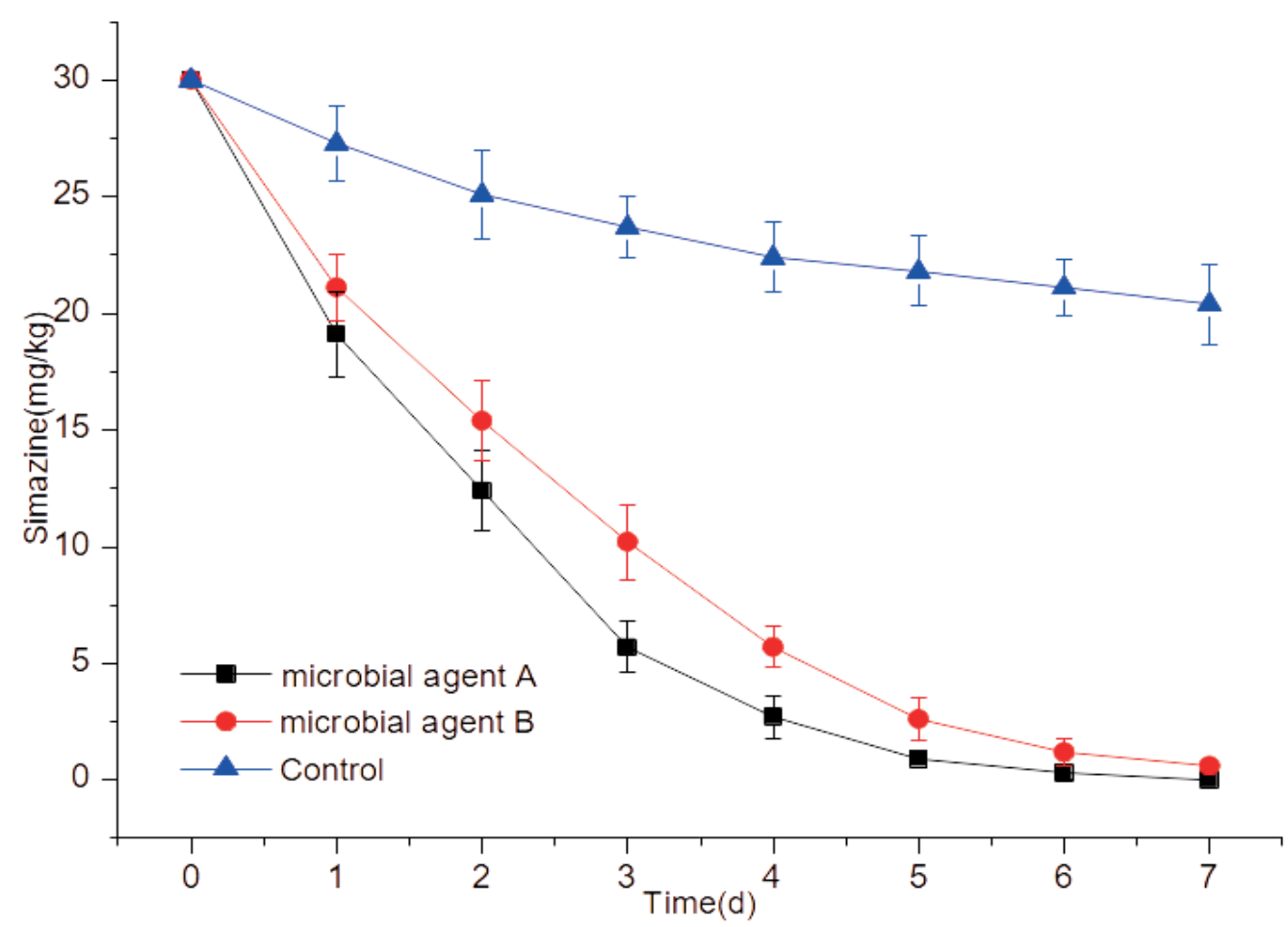

Figure 11.

The curve on degradation of simazine in soil by microbial agent (Microbial agent B did not contain the rhizosphere soil of Pennisetum) $(n=5)$. 


\section{CONCLUSIONS}

2 simazine degrading strains were isolated from soil, and they were Bacillus lichen iformis SIMA-N5 and Bacillus altitudinis SIMA-N9, respectively. The strain SIMA-N9 degraded simazine slightly faster than SIMA-N5. The combined application of strain SIMA-N5 and strain SIMA-N9 could not achieve higher degradation efficiency, which should be attributed to the competition or antagonism between the two strains. In addition, Pennisetum rhizosphere soil could effectively improve the biodegradation efficiency of simazine by strain SIMA-N9. It was concluded that the pennisetum rhizosphere soil solution sterilized by filtration may contain some enzymes or other compounds that could promote the degradation of simazine. The promotion effect of Pennisetum rhizosphere soil on the biodegradation of s-triazine herbicides was confirmed again, but the related mechanism need to be further studied. The strain SIMA-N9 had been successfully prepared as a microbial agent for degradation of simazine residues in soil. The microbial agent containing SIMA-N9 and Pennisetum rhizosphere soil had achieved satisfactory experimental results, and the degradation efficiency of simazine $(30 \mathrm{mg} /$ $\mathrm{kg}$ ) by this microbial agent could reach $97 \%$ after $5 \mathrm{~d}$. These results suggested that strain SIMA-N9 and its microbial agent could be used to treat simazine pollution.

\section{Acknowledgments}

This study was funded by the National Key Research and Development Plan of China (No. 2016YFD0600204) and China Postdoctoral Science Foundation (No.2017M611827), and partially by the Priority Academic Program Development of Jiangsu Higher Education Institutions. The authors declare that they have no known competing financial interests or personal relationships that could have appeared to influence the work reported in this paper.

\section{REFERENCES}

ADDORISIO V, PIROZZI D, ESPOSITO S \& SANNINO F. 2011. Decontamination of waters polluted with simazine by sorption on mesoporous metal oxides. J Hazard Mater 196: 242-247.

BEHKI RM \& KHAN SU. 1994. Degradation of atrazine, propazine, and simazine by Rhodococcus strain B-30. J Agr Food Chem 42(5): 1237-1241.

BLASZAK M, PELEC R \& GRACZYK P. 2011. Screening of microorganisms for biodegradation of simazine pollution (Obsolete Pesticide Azotop 50 WP). Water Air Soil Poll 220: 373-385.

CARACCIOLO AB, GRENNI P, CICCOLI R \& LANDA GD. 2005. Simazine biodegradation in soil: analysis of bacterial community structure by in situ hybridization. Pest Manag Sci 61(9): 863-869.

CARACCIOLO AB, GRENNI P, MARIA LS \& FALCONI F. 2007. The role of the bacterial community of an agroecosystem in simazine degradation. Ital J Agron 2(2): 163-170.

CASTRO-GONZÁLEZ A, PRIETO-JIMÉNEZ D, DOMÍNGUEZ-VÉLEZ A \& MERINO-CASTRO G. 2011. Biological degradation of simazine by mixed-microbial cultures immobilized on sepiolite and tepojal beads. Water Environ Res 83(3): 274-288.

CHEN W, MO J, DU X, ZHANG Z \& ZHANG W. 2019. Biomimetic dynamic membrane for aquatic dye removal. Water Res 151: 243-251.

CHO YS, LEE BU \& OH KH. 2008. Simultaneous degradation of nitroaromatic compounds TNT, RDX, atrazine, and simazine by Pseudomonas putida HK-6 in bench-scale bioreactors. J Chem Tech Biotech 83: 1211-1217.

CHUNG IM, PARK IM \& KIM SH. 2011. Development and comparison of analytical methods for measuring simazine herbicide using gas chromatography/ion trap, gas chromatography/mass selective detector, and high performance liquid chromatography/triple quadrupole mass spectrometers. J Korean Soc Appl Bi 54: 744-749.

DAUDA AB, AJADI A, TOLA-FABUNMI AS \& AKINWOLE AO. 2019. Waste production in aquaculture: Sources, components and managements in different culture systems. Aquac Fish 4(3): 81-88.

DING S, WANG Y, LU L, ZHANG Y, JIANG M, WEI Q \& YE J. 2019. Isolation-screening and identification of an endophytic bacteria in Ceresas with resistance to Agrobacterium tumefaciens and phosphorus solubilizing ability. J Nanjing Forest Univ 43(5): 81-88. 
DOUGLASS JF, RADOSEVICH M \& TUOVINEN OH. 2017. Microbial attenuation of atrazine in agricultural soils: biometer assays, bacterial taxonomic diversity, and catabolic genes. Chemosphere 176: 352-360.

FAN R, HE X, YE W, CAI Z \& HU S. 2020. Isolation, identification and growth inhibition of microorganisms mildew of fiberboard. J Forest Eng 5(5): 84-89.

FLORES C, MORGANTE V, GONZÁLEZ M, NAVIA R \& SEEGER M. 2009. Adsorption studies of the herbicide simazine in agricultural soils of the Aconcagua valley, central Chile. Chemosphere 74: 1544-1549.

GARMOUMA M, BLANCHOUD H, BLANCHARD M \& CHEVREUIL $M$. 2001. Triazines in the marne and the seine rivers (France) longitudinal evolution and flows. Water Air Soil Poll 132: $1-17$.

GRIGG BC, BISCHOFF M \& TURCO RF. 1997. Cocontaminant effects on degradation of triazine herbicides by a mixed microbial culture. J Agr Food Chem 45(3): 995-1000.

GUO Q, ZHANG J, WAN R \& XIE S. 2014. Impacts of carbon sources on simazine biodegradation by Arthrobacter strain SD3-25 in liquid culture and soil microcosm. Int Biodeter Biodegr 89: 1-6.

HERNANDEZ M, VILLALOBOS P, MORGANTE V, GONZALEZ M \& MOORE E. 2010. Isolation and characterization of a novel simazine-degrading bacterium from agricultural soil of central Chile, Pseudomonas sp. MHP41. FEMS Microbiol Lett 286(2): 184-190.

HERRERA H, PALMA G, ALMONACID L, CAMPOS R, FUENTES A \& ARRIAGADA C. 2019. Improving soil simazine dissipation through an organic amendment inoculated with Trametes versicolor. J Soil Sci Plant Nut 19: 262-269.

ISLAM MM, BARMAN A, KUNDU GK, KABIR MA \& PAUL B. 2019. Vulnerability of inland and coastal aquaculture to climate change: Evidence from a developing country. Aquac Fish 4(5): 183-189.

IWASAKI A, TAKAGI K, YOSHIOKA Y, FUJII K, KOJIMA Y \& HARADA N. 2007. Isolation and characterization of a novel simazinedegrading $\beta$-proteobacterium and detection of genes encoding s-triazine-degrading enzymes. Pest Manag Sci 63: 261-268.

JIN Y, CHEN H, WU W \& WEI W. 2020. Investigations of the effect of water-soluble lignin on enzymatic hydrolysis of lignocellulose. J Forest Eng 5(4): 12-19.

JOSÉ M, ALICIA G, CARMEN L, MAR N, RAQUEL V \& CARLOS G. 2010. Evaluation of the atzB gene as a functional marker for the simazine-degrading potential of an agricultural soil. Appl Soil Ecol 45: 218-224.
KANG J, JIN C, LI Z, WANG M, CHEN Z \& WANG Y. 2020. Dual Z-scheme $\mathrm{MOS}_{2} / \mathrm{g}-\mathrm{C}_{3} \mathrm{~N}_{4} / \mathrm{Bi}_{24} \mathrm{O}_{31} \mathrm{Cl}_{10}$ ternary heterojunction photocatalysts for enhanced visible-light photodegradation of antibiotic. J Alloy Comp 825: 153975.

KEARNEY PC, KAUFMAN DD \& SHEETS TJ. 1965. Fungal metabolism of herbicides, metabolites of simazine by aspergillus fumigatus. J Agr Food Chem 13(4): 369-372.

KOU X, XIE N, WU C, FAN G \& FU X. 2020. Isolation and identification of endophytic fungi from Cyclocarya paliurus (Batal.) Iljinskaja. J Nanjing Forest Univ 44(2): 26-34.

LI L, ZHANG Y, ZHENG L, LU S, YAN Z \& LING J. 2018. Occurrence, distribution and ecological risk assessment of the herbicide simazine: A case study. Chemosphere 204: 442-449.

LIAO M \& XIE X. 2008. Effects of combination of plant and microorganism on degradation of simazine in soil. J Environ Sci 20: 195-198.

LU W, GENG H, ZHANG Y \& RUAN H. 2020. Effects of biochars pyrolyzed at different temperatures on soil microbial community in a poplar plantation in coastal eastern China. J Nanjing Forest Univ 44(4): 143-150.

MARRIAGE PB, SAIDAK WJ \& VON SFG. 2010. Residues of atrazine, simazine, linuron and diuron after repeated annual applications in a peach orchard. Weed Res 15(6): 373-379.

MENG S, MENG X, FAN W, LIANG D, WANG L, ZHANG W \& LIU Y. 2020. The role of transparent exopolymer particles (TEP) in membrane fouling: A critical review. Water Res 181: 115930 .

MIN L, GUO L \& YE J. 2019. Mechanism of Burkholderia pyrrocinia JK-SH007 growth-promoting to plant via sidero-phore-mediation. J Nanjing Forest Univ 43(6): 165-172.

MONDRAGÓN-PARADA ME, RUIZ-ORDAZ N, TAFOYA-GARNICA A \& GALÍNDEZ-MAYER J. 2008. Chemostat selection of a bacterial community able to degrade s-triazinic compounds: continuous simazine biodegradation in a multi-stage packed bed biofilm reactor. J Ind Microbiol Biot 35: 767-776.

MORÁN AC, MÜLLER A, MANZANO M \& GONZÁLEZ B. 2010. Simazine treatment history determines a significant herbicide degradation potential in soils that is not improved by bioaugmentation with Pseudomonas sp. ADP. J Appl Microbiol 101: 26-35.

MORGANTE V, FLORES C, FADIC X, GONZALEZ M \& CERECEDABALIC F. 2012. Influence of microorganisms and leaching 
on simazine attenuation in an agricultural soil. J Environ Manage 95: S300-305.

MORGANTE V, LOPEZ-LOPEZ A, FLORES C, GONZALEZ M, ROSSELLO-MORA R \& SEEGER M. 2010. Bioaugmentation with pseudomonas sp. strain MHP41 promotes simazine attenuation and bacterial community changes in agricultural soils. FEMS Microbiol Ecol 71(1): 114-126.

NAVARRO S, OLIVA J, BARBA A \& GARCÍA IZQUIERDO C. 2000. Determination of simazine, terbutilazine and their dealkilated chlorotriazine metabolites in soil using sonication microextraction and gas chromatography. J AOAC Int 83(5): 1239-1243.

RAQUEL SM, FABRICE ML, PRADO RD \& FRANCO AR. 2005. Degradation of simazine by microorganisms isolated from soils of Spanish olive fields. Pest Manag Sci 61(9): 917-921.

SAI L, LIU Y, QU B \& YU G. 2015. The effects of simazine, a chlorotriazine herbicide, on the expression of genes in developing Male Xenopus laevis. B Environ Contam Tox 95: 157-163.

SATHISHKUMAR P, MANGALARAJA RV, MANSILLA HD, GRACIAPINILLA MA \& ANANDAN S. 2014. Sonophotocatalytic (42kHz) degradation of simazine in the presence of $\mathrm{Au}-\mathrm{TiO}_{2}$ nanocatalysts. Appl Catal B-Environ 160-161: 692-700.

SATSUMA K. 2010. Mineralization of s-triazine herbicides by a newly isolated nocardioides species strain DN36. Appl Microbiol Biot 86(5): 1585-1592.

SILVA M \& IYER P. 2014. Toxicity endpoint selections for a simazine risk assessment. Birth Defects Res B 101(4): 308-324.

SILVIA PGN, OSWALDO RM, NORA RO, ANGÉLICA SA, CLEOTILDE JR \& DEIFILIA AC. 2011. Simultaneous degradation of atrazine and simazine by a binary culture of Stenotrophomonas maltophilia and Arthrobacter sp. in a two-stage biofilm reactor. J Chem Technol Biot 86: 554-561.

SINGH N, MEGHARAJ M, KOOKANA RS, NAIDU R \& SETHUNATHAN N. 2004. Atrazine and simazine degradation in Pennisetum rhizosphere. Chemosphere 56: 257-263.

SONG J, XU G, ZHAO X, YAO Y, YANG X, TANG R, CUI J, CHEN F \& REN J. 2020. Screening of indigenous phosphate-solubilizing bacteria from Liquidambar formosana Hance rhizosphere and its potential applications for improving plant growth. J Nanjing Forest Univ 44(3): 95-104.

SPURLOCK F, BUROW K \& DUBROVSKY N. 2000. Chlorofluorocarbon dating of herbicide-containing well waters in fresno and tulare counties, California. J Environ Qual 29: 474-483.
WAN R, YANG Y, SUN W, WANG Z \& XIE S. 2014. Simazine biodegradation and community structures of ammoniaoxidizing microorganisms in bioaugmented soil: impact of ammonia and nitrate nitrogen sources. Environ Sci Pollut Res Int 21(4): 3175-3181.

WANG Q \& XIE S. 2012. Isolation and characterization of a high-efficiency soil atrazine-degrading Arthrobacter sp. strain. Int Biodeter Biodegr 71: 61-66.

WANG S, ZHANG C \& YAN Y. 2012. Biodegradation of methyl parathion and $p$-nitrophenol by a newly isolated Agrobacterium sp. strain Yw12. Biodegradation 23: 107-116.

XIA J, ZHOU N, ZHOU C, CHEN B, WU Y \& YAO S. 2015. Simultaneous determination of melamine and related compounds by hydrophilic interaction liquid chromatography-electrospray mass spectrometry. I Sep Sci 33: 2688-2697.

XU P, WU C, FAN G, ZHANG C, GAO X, BIAN Y \& CHEN S. 2019. Preparation and characteristic evaluation of Lactobacillus plantarum microcapsules developed with the ginkgo seed protein and sodium alginate. J Forest Eng 4(5): 70-77.

XU R, ZHANG X, PAN Y, ZHANG Y, LI X \& WANG F. 2020. Expression, purification and characterization of lipase from Thermosyntropha lipolytica. J Forest Eng 5(3): 108-114.

ZHANG G, ZHANG Q, SUN K, LIU X, ZHENG W \& ZHAO Y. 2011. Sorption of simazine to corn straw biochars prepared at different pyrolytic temperatures. Environ Pollut 159: 2594-2601.

ZHANG W \& JIANG F. 2019. Membrane fouling in aerobic granular sludge (AGS)-membrane bioreactor (MBR): effect of AGS size. Water Res 157: 445-453.

ZHANG W, LIANG W, ZHANG Z \& HAO T. 2021. Aerobic granular sludge (AGS) scouring to mitigate membrane fouling: performance, hydrodynamic mechanism and contribution quantification model. Water Res 188: 116518.

ZHAO Y, ZHAO C, TONG S \& JIN C. 2019. Study on isolation and utilization of a chlorothalonil degrading bacterium, Bacillus coagulans BJQ-Z6. Fresen Environ Bull 28: 2426-2432.

ZHU J, FU L, JIN C, MENG Z \& YANG N. 2019a. Study on the isolation of two atrazine-degrading bacteria and the development of a microbial agent. Microorganisms 7(3): 80.

ZHU J, FU L, MENG Z \& JIN C. 2021. Characteristics of an atrazine degrading bacterium and the construction of a 
microbial agent for effective atrazine degradation. Water Environ J 35: 7-17.

ZHU J, ZHAO Y, FU L, LIU Z, LI X \& MENG Z. 2020a. Application of a simazine degrading bacterium, Arthrobacter ureafaciens XMJ-Z01 for bioremediation of simazine pollution. Water Environ J 34: 561-572.

ZHU J, ZHAO Y, LI X, CHEN W \& HUANG R. 2018. Study on the characteristics and utilization of a triclopyr butoxyethyl ester degrading bacterium, Lactobacillus buchneri TBE6. Fresen Environ Bull 27(5): 3156-3161.

ZHU L, WU S, OUYANG S, TANG S \& LI X. 2019b. Effect of addition of amino acids on production of hyaluronic acid by Streptococcus zooepidemicus. J Forest Eng 4(3): 74-79.

ZHU Z, CHEN Z, LUO X, ZHANG W \& MENG S. 2020b. Gravitydriven biomimetic membrane (GDBM): An ecological water treatment technology for water purification in the open natural water system. Chem Eng J 399: 125650.

\section{How to cite}

ZHU J, ZHAO Y, LI X, WU L, FU L, YANG N, YIN J \& HUANG R. 2021. Isolation of 2 simazine-degrading bacteria and development of a microbial agent for bioremediation of simazine pollution. An Acad Bras Cienc 93: e20210373. DOI 10.1590/0001-3765202120210373.

Manuscript received on March 11, 2021;

accepted for publication on April 27, 2021

\section{JIANGWEI ZHU}

https://orcid.org/0000-0003-0913-3435

\section{YAN ZHAO}

https://orcid.org/0000-0001-9080-5256

\section{XIAOLOU LI ${ }^{3}$}

https://orcid.org/0000-0002-9401-6753

\section{LEI WU}

https://orcid.org/0000-0002-9733-5573

\section{FU}

https://orcid.org/0000-0002-5957-7790

\section{NING YANG ${ }^{6}$}

https://orcid.org/0000-0002-2737-4147

\section{JUN YIN}

https://orcid.org/0000-0002-3540-9223

\section{RONG HUANG}

https://orcid.org/0000-0001-8355-6925

${ }^{1}$ Nanjing Forestry University, Co-Innovation Center for Sustainable Forestry in Southern China, No. 159, Longpan Road, 210037, Nanjing, China

${ }^{2}$ Shanghai Institute of Quality Inspection and Technical Research, No. 381, Cangwu Road, Xuhui District, 200233, Shanghai, China

${ }^{3}$ Sichuan Vocational and Technological College, Architecture and Environmental Engineering Department, No. 1, Xuefu North Road, 629000, Suining, China

${ }^{4}$ Shandong Medical College, Department of Medical Examination, No. 5460, Erhuan'nan Road, 250002, Jinan, China

${ }^{5}$ Hangzhou Dianzi University, College of Materials and Environmental Engineering, No. 1158, No. 2 Baiyang Street, 310018, Hangzhou, China

${ }^{6} J$ i'nan Landscape Flower and Plantlet Breeding Center, No. 30899, Jingshi East Road, 250103, Jinan, China ${ }^{7}$ Pudong Agrotechnology Extension Center, No. 386, Pailou Road, 201201, Shanghai, China

\section{Correspondence to: Lei Wu}

Email:1817367670@qq.com

\section{Author contributions}

All authors contributed to the study conception and design. Material preparation, data collection and analysis were performed by Jiangwei Zhu, Yan Zhao and Lei Wu. Xiaolou Li, Li Fu, Ning Yang and Jun Yin supervised both the experimental design and data acquisition. The first draft of the manuscript was written by Jiangwei Zhu and Rong Huang, and all authors commented and corrected the manuscript. All authors have read and approved the final manuscript.

\section{(cc) BY}

